\title{
Molecular Cloning of a pIP501 Derivative Yields a Model Replicon for the Study of Streptococcal Conjugation
}

\author{
By R. PAUL EVANS,${ }^{1} \dagger$ ROBERT B. WINTER ${ }^{2}$ AND \\ FRANCIS L. MACRINA ${ }^{1 *}$ \\ ${ }^{1}$ Department of Microbiology and Immunology, Virginia Commonwealth University, Richmond, \\ Virginia 23298, USA \\ 2 Department of Molecular, Cellular and Developmental Biology, University of Colorado, \\ Boulder, Colorado 80309, USA
}

(Received 20 June 1984; revised 29 August 1984)

\begin{abstract}
We have previously constructed a derivative of the broad host range streptococcal plasmid pIP501, a conjugative plasmid designated pVA797, that confers chloramphenicol resistance and contains a unique EcoRI site in a non-essential region of the plasmid molecule. pVA797 $(30.7 \mathrm{~kb})$ when cloned in toto as an EcoRI fragment into the positive selection vector pOP203( $\left.\mathrm{A}_{2}{ }^{+}\right)$gave a recombinant, pVA904 $(37.7 \mathrm{~kb})$, which was able to replicate in Escherichia coli and in streptococcal species. It can be phenotypically monitored in either genus by specific drug resistance markers (chloramphenicol resistance in streptococci, tetracycline resistance in $E$. coli). pVA904 segregates into $E$. coli minicells where it specifies the production of at least 13 polypeptides. Many of the polypeptides are missing in minicells containing a transfer-defective, deletion derivative of pVA904. pVA904 is an ideal model replicon for the study of streptococcal conjugation because it is a shuttle plasmid thus enabling manipulation using procedures established for E. coli. Specifically, it should be possible to define the genetic basis of streptococcal conjugation by coupling mutagenesis protocols and minicell protein analyses in $E$. coli with evaluation of transfer function in streptococci.
\end{abstract}

\section{INTRODUCTION}

Streptococcal plasmids capable of self-transfer were first described by Jacob \& Hobbs (1974). Since then, conjugative plasmids or non-plasmid elements have been reported in several of the Lancefield groups of streptococci (for review see Clewell, 1981). Although many of these elements are restricted in host range, a number of plasmids have been described that are capable of inter- and intrageneric transfer among a wide range of species.

The plasmids pAM $\beta 1$ [Lancefield group D origin; confers erythromycin resistance $(\mathrm{Em})]$ and pIP501 [Lancefield group B origin; confers chloramphenicol resistance $(\mathrm{Cm})$ and $\mathrm{Em}$ ] are among the broad host range streptococcal resistance plasmids which have received considerable attention. pAM $\beta 1$ and pIP501 have been shown to transfer by a conjugation-like mechanism to at least nine streptococcal species (Hershfield, 1979; Malke, 1979; Engel et al., 1980; Gasson \& Davies, 1980) as well as to Lactobacillus casei (Gibson et al., 1979), Staphylococcus aureus (Engel et al., 1980), and Pediococcus spp. (Gonzalez \& Kunka, 1983).

Recently we have characterized the conjugal plasmid pIP501 with regard to its restriction endonuclease site map and the molecular organization of its antibiotic resistance determinants and replication region (Evans \& Macrina, 1983). In addition, we have detailed the construction of a conjugative derivative of pIP501, pVA797 $(30.7 \mathrm{~kb})$, which bears only the Cm determinant and a single $E c o$ RI site in a dispensable region of the plasmid. Its erythromycin-sensitive, $\mathrm{Cm}$

† Present address: Agronomy Department, Purdue University, West Lafayette, Indiana 47906, USA. 
phenotype and its conjugal donor ability make pVA797 a useful genetic tool (Evans \& Macrina, 1983; M. Smith and D. B. Clewell, unpublished observations) for mobilizing recombinant or native plasmids. pVA797 also provides a novel means to explore the genetic organization of broad host range streptococcal plasmids. Its somewhat elevated copy number and genetic stability relative to pIP501 facilitate its physical isolation. Most importantly, the unique EcoRI site of pVA797 affords strategies for its genetic manipulation.

This paper reports the successful molecular cloning of pVA797 as a single $30.7 \mathrm{~kb}$ EcoRI fragment using the positive selection vector pOP203( $\mathrm{A}_{2}^{+}$) (Winter \& Gold, 1983). This recombinant plasmid, designated pVA904, replicated in Streptococcus as well as in Escherichia coli. As expected, it retained its conjugal donor-conferring ability in streptococci. pVA904 conferred low level chloramphenicol resistance in $E$. coli, probably directed by the streptococcal resistance determinant. pVA904 segregates into $E$. coli minicells and directs the synthesis of several polypeptides. Specific proteins are missing when a non-conjugative, deletion-bearing derivative of this plasmid is monitored in the minicell system. pVA904 provides a model replicon for studying the genetic basis of conjugative donor ability conferred by broad host range streptococcal plasmids.

\section{METHODS}

Bacterial strains and media. The strains used in this work are listed in Table 1. Streptococcal strains were grown routinely in brain heart infusion broth or Todd-Hewitt broth (Difco) at $37^{\circ} \mathrm{C}$ under anaerobic conditions. E. coli strains were grown in L-broth (Maniatis et al., 1982) under aerobic conditions. Solid medium was made by the addition of $1.5 \%(\mathrm{w} / \mathrm{v})$ agar (Difco) to broth. Chloramphenicol and rifampin were used in selective media for streptococci at concentrations of 5 and $50 \mu \mathrm{g} \mathrm{ml}^{-1}$, respectively. Selective media for $E$. coli strains contained chloramphenicol, tetracycline, and rifampin at concentrations of 25,10 and $50 \mu \mathrm{g} \mathrm{m}^{-1}$, respectively. Isopropyl thio- $\beta$-D-galactoside (IPTG) was used at a final concentration of $10^{-3} \mathrm{M}$ in solid media.

Plasmid DNA isolation and characterization. Covalently closed circular (CCC) plasmid was isolated from streptococcal strains by a modification of the method of Hansen \& Olsen (1978) as described by Tobian \& Macrina (1982). The method of Clewell \& Helinski (1970) was used for the isolation of $E$. coli plasmids. $E$. coli strains were rapidly screened for plasmid DNA by an adaptation of a method obtained from M. Rosenberg (Tobian \& Macrina, 1982). Streptococcal strains were screened for plasmid DNA by the same method with minor modification. Specifically, $0.01 \mathrm{mg}$ mutanolysin $\mathrm{ml}^{-1}$ (a gift from Kanae Yokogawa, Dainippon Pharmaceutical Co., Osaka, Japan) instead of $1 \mathrm{mg}$ lysozyme $\mathrm{ml}^{-1}$ was added to the lysis buffer [50 mM-Tris, pH $8.0,50 \mathrm{~mm}$ EDTA, $15 \%(\mathrm{w} / \mathrm{v})$ sucrose] and the cell suspension was incubated for $1 \mathrm{~h}$ at $37^{\circ} \mathrm{C}$ instead of $0{ }^{\circ} \mathrm{C}$ for $10 \mathrm{~min}$. Purified plasmid DNA and plasmid restriction digestion products were analysed by electrophoresis through agarose (Meyers et al., 1976) with appropriate size reference CCC plasmid DNA (Macrina et al., 1978) or linear phage $\lambda$ DNA digested with HindIII (BRL).

Restriction endonucleases and T4 DNA ligase were purchased from BRL and used according to the manufacturer's instructions.

Genetic techniques. S. sanguis was genetically transformed according to the procedure of Lawson \& Gooder (1970). E. coli was transformed by the standard $\mathrm{CaCl}_{2}$-heat shock method (Davis et al., 1980), except that cells were harvested at an $\mathrm{OD}_{660}$ of 0.2 rather than 0.5 . Conjugal matings on filters $(6 \mathrm{~h}$ duration) were done as previously described (Evans \& Macrina, 1983).

Purification of minicells and electrophoretic analysis of minicell lysates. E. coli minicells were purified and labelled essentially as described by Kennedy et al. (1977) except that before radioisotopic labelling, D-cycloserine was added to the minicell suspension at a final concentration of $40 \mu \mathrm{g} \mathrm{ml}^{-1}$. Proteins were labelled by incubation with $20 \mu \mathrm{Ci}\left[{ }^{35}\right.$ S $]$ methionine $\mathrm{ml}^{-1}$ (ICN, Cleveland, Oh., USA). Minicell lysates were examined by SDSpolyacrylamide gel $(10 \%, \mathrm{w} / \mathrm{v}$, acrylamide) electrophoresis (SDS-PAGE) by standard methods (Laemmli \& Favre, 1973). Autoradiographic detection of ${ }^{35} \mathrm{~S}$-labelled proteins was done at $-70{ }^{\circ} \mathrm{C}$ for $48 \mathrm{~h}$ using Kodak X-OMAT R film. The molecular weights of the proteins were estimated by comparison to the migration of low and high molecular weight protein standards (Pharmacia).

\section{RESULTS \\ Construction of pVA904}

Earlier attempts to clone fragments of pIP501 carrying genetic information for conjugal transfer were unsuccessful (Evans \& Macrina, 1983). Similarly, deletion mapping of pIP501 derivatives did not allow location of specific regions governing conjugative ability. Accordingly, 


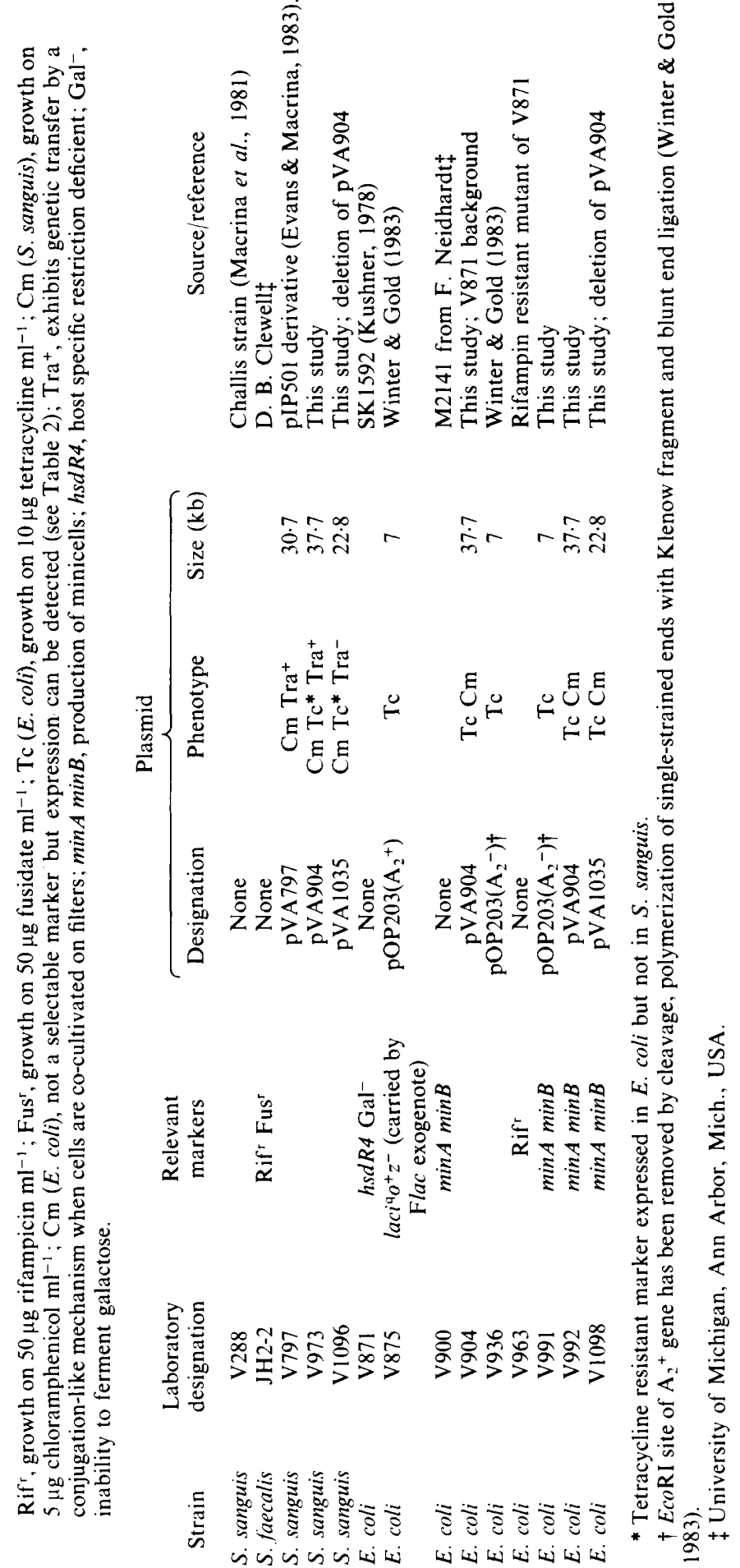




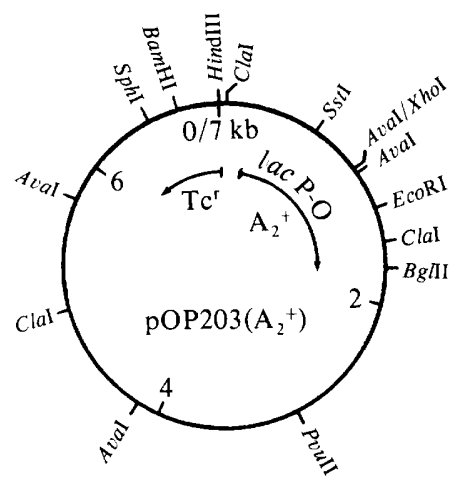

Fig. 1. Restriction endonuclease site map of pOP203( $\left.\mathrm{A}_{2}^{+}\right)$. A restriction endonuclease site map of pOP203 $\left(\mathrm{A}_{2}{ }^{+}\right)$, originally published by Winter \& Gold (1983), was expanded detailing the restriction sites for PvuII, ClaI and AvaI. The segment bearing the lactose promoter-operator (lac $\mathrm{PO}$ ) and the $\mathrm{A}_{2}$ gene from $\mathrm{Q} \beta$ phage $\left(\mathrm{A}_{2}{ }^{+}\right)$and the tetracycline resistance determinant (labelled $\mathrm{Tc}^{r}$ ) are delineated on the inside of the map. The positions of the arrows indicate the direction of transcription of both the tetracycline resistance and $\mathrm{A}_{2}$ genes. The EcoRI, Sst I, XhoI or $B g / I I$ sites of pOP203( $\left.{ }_{2}^{+}\right)$may be used to insertionally inactivate the $\mathrm{A}_{2}$ gene.

we attempted to clone the pIP501 derivative, pVA797 (Evans \& Macrina, 1983), by taking advantage of a unique EcoRI site in a non-essential region of this plasmid (Evans \& Macrina, 1983). The large size of pVA797 $(30.7 \mathrm{~kb})$ dictated that we consider novel vectors for cloning this plasmid as a single fragment. For this purpose, we used the positive selection vector pOP203 $\left(\mathrm{A}_{2}{ }^{+}\right)$constructed by Winter \& Gold (1983). This plasmid contains the $\mathrm{A}_{2}$ gene (maturation protein) of phage $\mathrm{Q} \beta$ inserted into the pOP203 plasmid [confers tetracycline resistance (Tc); Fuller, 1982] such that expression of the $\mathrm{A}_{2}$ gene product is under the control of the lactose operon promoter and operator. This plasmid may be stably maintained in $E$. coli strains that hyper-produce lactose repressor ( $i^{q}$ mutants) so as to ensure that no transcription of $A_{2}$ occurs. Induction of the lactose regulatory signals with IPTG results in cell death owing to production of $\mathrm{A}_{2}$ protein which mediates cellular lysis (Winter \& Gold, 1983). Expression of the $\mathrm{A}_{2}$ gene may be prevented by in vitro insertional inactivation at one of several restriction endonuclease sites (see Fig. 1). This allows direct and efficient selection for chimeric plasmids carrying inserts in the $\mathrm{A}_{2}$ gene. EcoRI-cleaved pOP203( $\left.\mathrm{A}_{2}{ }^{+}\right)$and pVA797 were mixed $1: 1$ $(0.3 \mu \mathrm{g}$ each), ligated and transformed into $E$. coli V871 with selection on L-media containing $10 \mu \mathrm{g}$ tetracycline $\mathrm{ml}^{-1}$ and $10^{-3} \mathrm{M}$-IPTG. Transformants were detected at frequencies of about $10^{-6}$ per survivor. In one experiment, 12 single transformant colonies were screened for recombinant plasmids. Three of the 12 clones yielded plasmids in the $37 \mathrm{~kb}$ size range. Five tetracycline resistant clones contained a plasmid similar in size to pOP203( $\left.\mathrm{A}_{2}^{+}\right)$while the remainder represented plasmids in the $10-20 \mathrm{~kb}$ range. The three $37 \mathrm{~kb}$ plasmids were analysed by restriction endonuclease cleavage and found to represent pOP203( $\left.\mathrm{A}_{2}^{+}\right):$:pVA797 chimeras joined at their EcoRI sites. One such plasmid was designated pVA904 and selected for further study. Fig. 2 illustrates the construction of pVA904. The pOP203( $\left.\mathrm{A}_{2}^{+}\right)$-like plasmids were $E c o$ RI resistant (assumed to be deletion derivatives) and the remaining plasmids in the $10-20 \mathrm{~kb}$ range had suffered deletions in their pVA797 sequences (not shown).

pVA904-containing $E$. coli strains formed colonies about one-fifth the size of corresponding non-plasmid-containing isolates. Such small colonies consistently gave rise to $1-5 \%$ large (wildtype) colonies upon continued sub-culture. These large tetracycline resistant colonies contained plasmids that resembled pOP203( $\left.\mathrm{A}_{2}^{+}\right)$in size; they were assumed to be large deletion derivatives of pVA904.

\section{Genetic transmission and expression studies}

Purified CCC pVA904 DNA was used to transform $S$. sanguis V288 to chloramphenicol resistance. The majority of such transformants contained plasmids that were indistinguishable 




Fig. 2. Construction of pVA904. EcoRI-linearized pVA797 [cleavage site within the pVA380-1 (thick line) portion] was ligated with EcoRI-linearized pOP203( $\left.\mathrm{A}_{2}^{+}\right)$(double line). The single thin line of pVA797 delineates regions of pIP501 origin. The location of the chloramphenicol resistance determinant (designated $\mathrm{Cm}^{\mathrm{T}}$ ) of pVA797 (Evans \& Macrina, 1983) and the tetracycline resistance determinant (designated $\mathrm{Tc}^{r}$ ) of pOP203( $\mathrm{A}_{2}{ }^{+}$) are noted on the inside of their respective maps. The ligation mixture was used to transform $E$. coli with selection for tetracycline resistance. The restriction enzyme sites are shown in parentheses to indicate that other such unmapped sites exist on the plasmids. The solid line inside the pVA904 map refers to the region that is missing in the corresponding deletion derivative, pVA1035. A more complete restriction endonuclease site map of pVA797 may be found in Evans \& Macrina (1983).

from pVA904 in both size and HindIII restriction fragment pattern. About $5 \%$ of the transformants obtained in this fashion had suffered deletions in the cloned pVA797 sequences. One such plasmid with a deletion of about $15 \mathrm{~kb}$ was designated pVA1035 and saved for further study. The extent of the deletion in pVA1035 is depicted in Fig. 2 on the inside of the circular pVA904 map. pVA1035 was introduced into $S$. sanguis V288 by transformation selecting for chloramphenicol resistance to produce strain V1096. S. sanguis containing pVA797, pVA904 and pVA1035 were compared with respect to conjugal donor ability (Table 2). As expected, pVA797 and pVA904 behaved similarly in terms of self-transmissibility (Table 2, lines 1 and 5). However, pVA1035 was incapable of promoting its self-transfer (Table 2, line 7). pVA904 could not promote the transfer of itself in Escherichia-Streptococcus intergeneric matings or in Escherichia-Escherichia matings (Table 2, lines 2, 3, 4 and 6).

Using a colony unit forming assay (see Table 3), S. sanguis or $S$. faecalis strains harbouring pVA904 were no more resistant to tetracycline than their isogenic plasmid-less counterparts (not shown). However, pVA904-containing derivatives of $E$. coli displayed reproducible elevation in 
Table 2. Conjugal transfer frequencies of $p V A 797, p V A 904$ and $p V A 1035$

\begin{tabular}{llllc}
\multicolumn{1}{c}{ Donor } & Plasmid & \multicolumn{1}{c}{ Recipient } & \multicolumn{1}{c}{$\begin{array}{c}\text { Antibiotics } \\
\text { used in } \\
\text { selection* }\end{array}$} & $\begin{array}{c}\text { Transfer } \\
\text { frequency }\end{array}$ \\
S. sanguis V797 & pVA797 & S. faecalis JH2-2 & Chloramphenicol & $1 \cdot 9 \times 10^{-3}$ \\
S. sanguis V797 & pVA797 & E. coli V963 & Chloramphenicol & $<10^{-8}$ \\
E. coli V904 & pVA904 & S. faecalis JH2-2 & Chloramphenicol & $<10^{-8}$ \\
E. coli V904 & pVA904 & E. coli V963 & Tetracycline & $<10^{-8}$ \\
S. sanguis V973 & pVA904 & S. faecalis JH2-2 & Chloramphenicol & $4 \cdot 3 \times 10^{-3}$ \\
S. sanguis V973 & pVA904 & E. coli V963 & Tetracycline & $<10^{-8}$ \\
S. sanguis V1096 & pVA1035 & S. faecalis JH2-2 & Chloramphenicol & $<10^{-8}$
\end{tabular}

* Drugs were used in selective media at the following concentrations: rifampin, $50 \mu \mathrm{g} \mathrm{ml}^{-1}$ was used to select against all donors: chloramphenicol, $5 \mu \mathrm{g} \mathrm{ml}^{-1}$, or tetracycline, $10 \mu \mathrm{g} \mathrm{ml}^{-1}$, were used to select for transconjugants.

$\dagger$ Transfer frequencies were expressed as drug resistant progeny per input donor cell at the initiation of mating. The filter mating method described in Methods was used in all mating combinations; filter matings were allowed to proceed for $6 \mathrm{~h}$ in all cases.

\title{
Table 3. Efficiency of plating on chloramphenicol for E. coli strains
}

\begin{abstract}
For each strain, an overnight culture was suitably diluted, and $0 \cdot 1 \mathrm{ml}$ was plated on at least three plates for each concentration tested. The c.f.u. (colony forming units) applied to each plate were between 500 and 800 . The average number of c.f.u. per plate at each antibiotic concentration was determined. Efficiency of plating = (average number of c.f.u. per plate at each antibiotic concentration/average number of c.f.u. on drug-free solid media) $\times 100$.
\end{abstract}

$\begin{array}{crrr}\begin{array}{l}\text { Chloramphenicol } \\ \text { concn }\left(\mu \mathrm{g} \mathrm{ml}^{-1}\right)\end{array} & \text { V900 } & \text { V992 } & \text { V992* } \\ 0 & 100 & 100 & 100 \\ 0 \cdot 1 & 80 & 89 & 99 \\ 0 \cdot 2 & 73 & 82 & 98 \\ 0 \cdot 5 & 53 & 77 & 96 \\ 1 & 3 & 71 & 84 \\ 2 & 0 & 68 & 62 \\ 5 & 0 & 1 & 7 \\ 10 & 0 & 0 & 0\end{array}$

* Grown in the presence of a sub-inhibitory level of chloramphenicol $\left(0.05 \mu \mathrm{g} \mathrm{m}^{-1}\right)$.

chloramphenicol resistance (Table 3, columns 2 and 3). Preincubation of cells in sub-inhibitory concentrations of chloramphenicol did not affect the estimated reistance levels (Table 3 , columns 3 and 4).

\section{Expression of $p V A 904$ and $p V A 1035$ in E. coli minicells}

pVA904 and its deletion derivative, pVA1035, were introduced by transformation into an $E$. coli minicell-producing mutant. Minicells were prepared by standard methods and plasmiddirected ${ }^{35}$ S-labelled polypeptides were detected by autoradiography following PAGE. Lane A in Fig. 3 represents the ${ }^{35} \mathrm{~S}$-labelled proteins made by minicells carrying the pOP203( $\left.\mathrm{A}_{2}^{-}\right)$ plasmid. This plasmid has had its $\mathrm{A}_{2}$ gene interrupted by removing the internal EcoRI site (Winter \& Gold, 1983; see Table 1). The protein seen below the 30000 dalton reference polypeptide corresponds to the predicted truncated version of the $\mathrm{A}_{2}$ gene product $(28600$ daltons; Winter \& Gold, 1983) as a result of interrupting the translational reading frame at the EcoRI site (see Fig. 1). A low molecular weight polypeptide (about 20000 daltons) seen in this lane was not identified.

Lane B of Fig. 3 displays the proteins encoded by pVA904 in E. coli minicells. At least 13 differently sized polypeptides were specified by pVA904. The truncated $\mathrm{A}_{2}$ gene product was not visible in lysates of pVA904-containing minicells. Readily distinguished polypeptide species marked by arrowheads in Fig. 3 had estimated sizes ranging from 25 to $77 \mathrm{kdal}$. The non- 
A

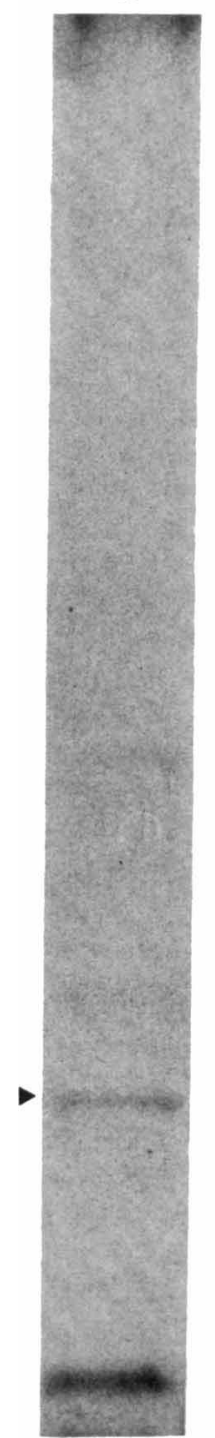

B



Fig. 3. Plasmid proteins synthesized in E. coli minicells. SDS-PAGE of $\left[{ }^{35}\right.$ S $]$ methionine-labelled minicell lysates was done as described in Methods. The locations of molecular weight reference molecules are shown by pointers ( $k d a l)$. A, proteins made by minicells containing pOP203( $\left.\mathrm{A}_{2}^{-}\right)$. The truncated $\mathrm{A}_{2}$ gene product (about $28 \mathrm{kdal}$ ) is arrowed. $\mathrm{B}$, analysis of pVA904-containing minicells; $\mathrm{C}$, analysis of pVA1035-containing minicells. Presumed plasmid specific proteins are arrowed.

conjugative pVA1035 plasmid (see Fig. 2) was unable to synthesize the majority of the proteins specified by pVA904. Only polypeptides of $25,27,32$ and $34 \mathrm{kdal}$ were synthesized in pVA1035containing minicells. All four of these polypeptides migrated similarly to corresponding polypeptides encoded by pVA904.

\section{DISCUSSION}

pVA904 provides a novel tool for exploring the basis of conjugal transfer encoded by broad host range plasmids in Gram-positive bacteria. Although the molecular cloning of specific 
plasmid fragments seems a viable approach to cloning genes governing conjugation, attempts of this sort to date have not met with success (Lee \& LeBlanc, 1983; Evans \& Macrina, 1983). It is possible that several unlinked genes control conjugal activity thus making the cloning of the phenotypic trait difficult if not impossible. With this in mind, we attempted to clone the entire pVA797 molecule into the EcoRI site of the conventional vector pACYC184 (Chang \& Cohen, $1978)$, but without success. The positive selection vector pOP203( $\left.\mathrm{A}_{2}^{+}\right)$afforded us the opportunity to achieve this goal. Even though the entire $30.7 \mathrm{~kb}$ pVA797 was cloned as a single fragment, it should be noted that apparent deletion derivatives of pOP203( $\left.\mathrm{A}_{2}^{+}\right):$:pVA797 chimeras were readily detected in transformants. We believe that one or more of the proteins encoded by pVA797 may be deleterious to $E$. coli and, hence, be prone to negative selective pressure. This would be consistent with the generation of large (fast growing) colonies from small (slow growing) colonies, the former carrying pVA904 deletion derivatives. This phenomenon awaits further investigation. Nonetheless, by maintaining the small colony type on media containing $10 \mu \mathrm{g}$ tetracycline $\mathrm{ml}^{-1}$ and $1 \mu \mathrm{g}$ chloramphenicol ml $\mathrm{ml}^{-1}$, we have succeeded in stably propagating $E$. coli strains carrying pVA904. Plasmid isolation is easily accomplished and minicell protein profiles are reproducible with strains grown in this fashion.

pVA904 may be classified as a shuttle plasmid being able to replicate in both Escherichia and Streptococcus. As expected, none of the identifiable phenotypic traits (drug resistance, replication, self-transmissibility) of pVA797 were altered by interrupting its EcoRI site (Evans \& Macrina, 1983). Although the tetracycline resistance determinant of pOP203 $\left(\mathrm{A}_{2}{ }^{+}\right)$was not expressed in $S$. sanguis, the chloramphenicol resistance determinant of pVA797 was expressed in E. coli (Table 3). However, this level of expression does not afford a genetic marker suitable for selection in transformation experiments. pVA904 conjugal donor proficiency was unaltered as compared to pVA797 in streptococci (Table 2). Not surprisingly, this $\mathrm{Tra}^{+}$phenotype was not expressed in $E$. coli (Table 2).

The analysis of pVA904-containing $E$. coli minicells indicates that several streptococcal plasmid genes are transcribed and translated in this sytem (Fig. 3). The polypeptide profiles on SDS-acrylamide gels were highly reproducible, making it unlikely that the multiple protein species were degradation products. Interestingly, the pVA1035 plasmid with an approximate $15 \mathrm{~kb}$ deletion failed to produce a substantial number of $\mathrm{pVA904-specified} \mathrm{polypeptides} \mathrm{in} \mathrm{the}$ minicell system. Because of the Tra- phenotype of pVA1035, it is reasonable to conclude that one or more of these missing proteins is involved in conjugal transfer.

The pVA904 plasmid opens novel avenues for exploring streptococcal plasmid functions, including conjugal transfer. It is possible now to mutagenize pVA904 in $E$. coli by controlled deletion formation or transposon insertion mutagenesis. Transformation of such mutant plasmids into $S$. sanguis allows the determination of conjugal functionality, while assessment of specific protein synthesis in minicells allows the correlation of map region with phenotype. We are using this approach to determine the number and location of conjugal donor proficiency genes on pVA904. Using immune sera raised against streptococcal cells carrying pVA904 it will be possible to immunoprecipitate pVA904-specified streptococcal cell surface proteins made in minicells. These are likely to be involved in at least the early stages of conjugal transfer. Most recently, we have found that at least one of the pVA904-specific minicell polypeptides is immunoprecipitated by immune serum prepared against pVA904-containing S. sanguis (D. L. Hartley \& F. L. Macrina, unpublished observations). Using these multiple approaches we hope to define the genetic and biochemical basis of conjugal transfer in this important class of transfer element.

We thank Donna Hartley for helpful discussions and Valencia Goodall for expert typing of the manuscript. This work was supported by a grant no. DE04224 from the National Institute of Dental Research, National Institutes of Health, USA. F. L. M. was the recipient of a Research Career Development Award from the National Institute of Dental Research (grant no. DE00081). R. P. E. was the recipient of a Virginia Commonwealth University School of Graduate Studies Fellowship Award. R. B. W. was a postdoctoral fellow of the Damon Runyon-Walter Winchell Cancer Fund (grant no. DRG-340-F). Work done in Boulder, Colo., was supported by National Institutes of Health (USA) grant no. GM28685 to Larry Gold. 


\section{REFERENCES}

Chang, A. C. Y. C. \& Cohen, S. N. (1978). Construction and characterization of amplifiable multicopy DNA vehicles derived from the P15A cryptic miniplasmid. Journal of Bacteriology 134, $1141-1156$

Clewell, D. B. (1981). Plasmids, drug resistance, and gene transfer in the genus Streptococcus. Microbiology Reviews 45, 409-436.

Clewell, D. B. \& Helinski, D. R. (1970). Properties of deoxyribonucleic acid-protein relaxation complex and strand specificity of the relaxation event. Biochemistry 9, 4428-4440.

Davis, R. W., Botstein, D. \& Roth, J. L. (1980). $A$ Manual for Genetic Engineering: Advanced Bacterial Genetics. Cold Spring Harbor: Cold Spring Harbor Laboratory.

Engel, H. W. B., Soedirman, N., Rost, J. A., van Leeuwen, W. J. \& van Embden, J. D. A. (1980). Transferability of macrolide, lincomycin, and streptogramin resistance between group A, B, and D streptococci, Streptococcus pneumoniae, and Staphylococcus aureus. Journal of Bacteriology 142, 407-413.

Evans, R. P. \& MaCRINA, F. L. (1983). Streptococcal R plasmid pIP501: endonuclease site map, resistance determinant location, and construction of novel derivatives. Journal of Bacteriology 154, 1347-1355.

FULLER, F. (1982). A family of cloning vectors containing the lacUV5 promoter. Gene 19, 43-54.

Gasson, M. J. \& Davies, F. L. (1980). Conjugal transfer of the drug resistance plasmid pAM $\beta$ in the lactic streptococci. FEMS Microbiology Letters 1, 51-53.

Gibson, E. M., Chase, N. M., London, S. B. \& LONDON, J. (1979). Transfer of plasmid-mediated antibiotic resistance from streptococci to lactobacilli. Journal of Bacteriology 137, 614-619.

Gonzalez, C. \& KunKa, B. S. (1983). Plasmid transfer in Pediococcus ssp.: intergeneric and intrageneric transfer of pIP501. Applied and Environmental Microbiology 46, 81-89.

HANSEN, J. B. \& OlSEN, R. H. (1978). Isolation of large bacterial plasmids and characterization of the P2 incompatibility group plasmids pMG1 and pMG5. Journal of Bacteriology 135, 227-238.

HeRSHFIELD, V. (1979). Plasmids mediating multiple drug resistance in group B streptococcus: transferability and molecular properties. Plasmid 2, 137-149.

JACOB, A. E. \& HoBBs, S. J. (1974). Conjugal transfer of plasmid-borne multiple antibiotic resistance in Streptococcus faecalis var. zymogenes. Journal of Bacteriology 117, 360-372.
Kennedy, N., Beutin, L., Achtman, M., Skurray, R., Rahmsdorf, U. \& Herrlich, P. (1977). Conjugation proteins encoded by the $\mathrm{F}$ sex factor. Nature, London 270, 580-585.

KUSHNER, S. (1978). An improved method for transformation of $E$. coli with ColEl-derived plasmids. In Genetic Engineering, pp. 17-23. Edited by H. Boyer \& S. Nicosia. Amsterdam: Elsevier Press.

LAEMmLI, U. K. \& FAVRE, M. (1973). Maturation of the head of bacteriophage T4. I. DNA packaging events. Journal of Molecular Biology 80, 575-599.

LAwSON, J. \& GOODER, H. (1970). Growth and development of competence in group $\mathrm{H}$ streptococci. Journal of Bacteriology 102, 820-825.

LeE, L. \& LeBlanc, D. (1983). Physical and genetic analyses of streptococcal plasmid pAM $\beta 1$ and cloning of its replication region. Journal of Bacteriology 157, 445-453.

MaCrina, F. L., Kopecko, D. J., Jones, K. R., Ayers, D. J. \& MCCOWEN, S. M. (1978). A multiple plasmid-containing Escherichia coli strain: convenient source of size reference plasmid molecules. Plasmid 1, 417-420.

Macrina, F. L., Jones, K. R. \& WoOd, P. H. (1981). Chimeric streptococcal plasmids and their use as molecular cloning vehicles in Streptococcus sanguis (Challis). Journal of Bacteriology 143, 1425-1435.

Malke, H. (1979). Conjugal transfer of plasmids determining resistance to macrolides, lincosamides and streptogramin-B type antibiotics among group A, B, $\mathrm{D}$ and $\mathrm{H}$ streptococci. FEMS Microbiology Letters 5 , 335-338.

Maniatis, T., Fritsch, E. F. \& Sambrook, J. (1982). Molecular Cloning: A Laboratory Manual. Cold Spring Harbor: Cold Spring Harbor Laboratory.

Meyers, J. A., Sanchez, D., Elwell, L. P. \& Falkow, S. (1976). Simple agarose gel electrophoresis method for the identification and characterization of plasmid deoxyribonucleic acid. Journal of Bacteriology 127, 1529-1538.

Tobian, J. A. \& Macrina, F. L. (1982). Helper plasmid cloning in Streptococcus sanguis: cloning of a tetracycline resistance determinant from the Streptococcus mutans chromosome. Journal of Bacteriology 152, 215-222.

WINTER, R. B. \& GoLD, L. (1983). Overproduction of bacteriophage $\mathrm{Q} \beta$ maturation $\left(\mathrm{A}_{2}\right)$ protein leads to cell lysis. Cell 33, 877-885. 